\title{
Double rhomboidal flap for reconstruction of large surgical defect of the labial commissure
}

\author{
Retalho romboidal duplo para reconstrução de defeito cirúrgico da \\ comissura labial
}

\author{
Pedro Andrade ${ }^{1}$ \\ Ricardo Vieira ${ }^{2}$
}

\author{
Ana Brinca ${ }^{1}$ \\ Américo Figueiredo ${ }^{3}$
}

\begin{abstract}
Closure of perioral surgical defects involving the oral commissures is highly challenging. We describe a 69-year-old male patient with a large basal cell carcinoma of the right perioral region, extending to the right oral commissure. This lesion was radically excised, and the resulting surgical defect was closed using a homolateral double opposing rhomboidal flap. The final result was esthetically very satisfactory, with total preservation of lip function. Double opposing rhomboidal flaps are viable surgical options for the reconstruction of surgical defects involving the perioral area and oral commissures. In this relatively simple procedure, donor skin is obtained from the nearby cheek and mandibular areas, under low risk of surgical complications, preserving lip function without distortion of the labial anatomy.
\end{abstract}

Keywords: Carcinoma, basal cell; Lip; Surgical flaps

Resumo: A abordagem de defeitos cirúrgicos da região perioral, em particular das comissuras labiais, é um desafio importante na prática cirúrgica dermatológica. Apresentamos o caso de um doente do sexo masculino, de 69 anos, com extenso carcinoma basocelular ulcerado da região perioral direita, com envolvimento da comissura labial. Foi realizada excisão radical da lesão e reconstrução do defeito cirúrgico com retalho romboidal duplo das regiões geniana e mandibular homolaterais. O resultado cosmético final foi satisfatório, com preservação da funcionalidade das estruturas labiais. O retalho romboidal duplo é uma alternativa viável para a reconstrução de defeitos cirúrgicos da comissura labial, de execução relativamente simples, com baixo risco de complicações, que oferece óptimos resultados funcionais e cosméticos, sem distorção da anatomia labial.

Palavras-chave: Carcinoma basocelular; Lábio; Retalhos cirúrgicos

Received on 17.05.2011.

Approved by the Advisory Board and accepted for publication on 13.07.2011

* Study carried out at the Dermatology and Venereology Service of the University of Coimbra Teaching Hospitals (Hospitais da Universidade de Coimbra), EPE - Coimbra, Portugal.

Conflict of interest: None

Financial funding: None

M.D. - Specializing in Dermatology and Venereology - Dermatology and Venereology Service of the University of Coimbra Teaching Hospitals (Hospitais da Universidade de Coimbra), EPE - Coimbra, Portugal.

M.D. - Specialist in Dermatology and Venereology - Hospital Assistant at the Dermatology and Venereology Service of the University of Coimbra Teaching Hospitals (Hospitais da Universidade de Coimbra), EPE - Coimbra, Portugal.

3 Ph.D. - Specialist in Dermatology and Venereology - Director of the Dermatology and Venereology Service of the University of Coimbra Teaching Hospitals (Hospitais da Universidade de Coimbra), EPE - Coimbra, Portugal. 


\section{INTRODUCTION}

Non-melanoma skin cancer is common on the face, namely on perioral skin. ${ }^{1,2,3}$ Squamous cell carcinomas predominate on the lower lip, particularly on the vermillion, and basal cell carcinomas are common on the upper lip. Any surgical procedure involving the perioral skin requires special attention concerning the preservation of cosmetic and functional properties of local structures, as small deformities may result in severe implications in facial symmetry, speech and oral continence.

\section{CASE REPORT}

We describe a 69-year old male patient who was observed with a $2.5 \mathrm{~cm}$ wide infiltrated, pigmented and centrally ulcerated plaque with unclearly delimited borders located on the right perioral region, extending to the ipsilateral oral commissure and distal melolabial fold, with progressive growth in the previous three years (Figure 1). This non-smoking patient reported intensive chronic sun exposure during his life and antecedents of stable angina pectoris, arterial hypertension and benign prostatic hyperplasia, regularly medicated with acetylsalicylic acid $100 \mathrm{mg}$ o.d., lisinopril $20 \mathrm{mg}$ o.d., simvastatin $20 \mathrm{mg}$ o.d. and isosorbid mononitrate $20 \mathrm{mg}$ o.d.

The histological analysis of an incisional biopsy was consistent with an ulcerated basal cell carcinoma, requiring radical excision. A double rhomboidal flap was considered for closure of the resulting surgical defect. Radical excision was performed under local anesthesia (lidocaine chloridrate $2 \%$ ), respecting the limits of a previously defined triangular area centered in the tumour, with posterior vertex and parasagittal anterior base lining medial to the right oral commis-

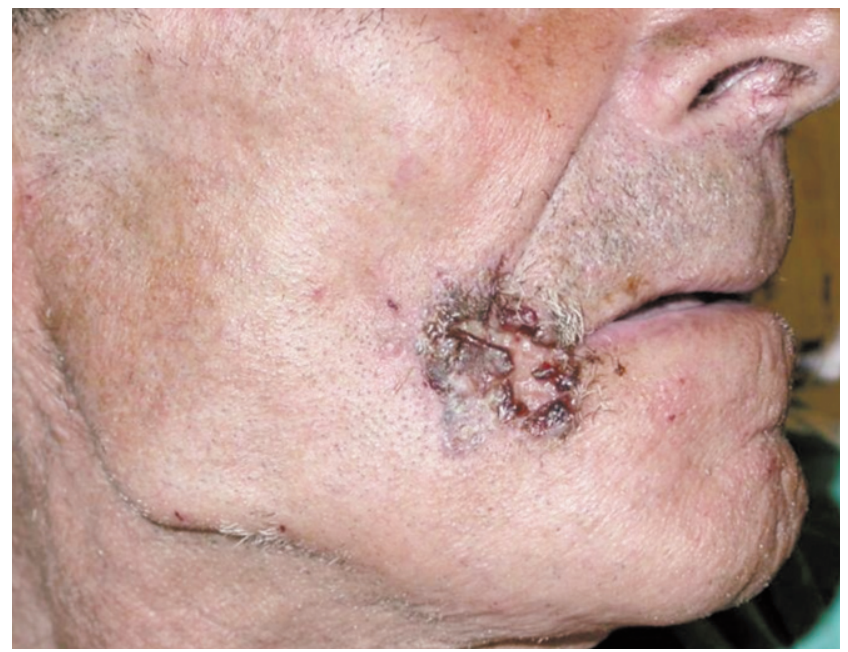

FIGURE 1: Large ulcerated basal cell carcinoma on the right perioral region, extending to the right oral commissure sure. This triangle included the whole tumour and the conventional surrounding $4 \mathrm{~mm}$ surgical margins (Figure 2). Simultaneously, two rhomboidal donor areas were defined on the cheek and mandibular region by two lines placed parallel to each triangle side respecting a $2 \mathrm{~cm}$ interval, the former partially matching with the nasolabial fold. After tumour excision and careful hemostasis using bipolar elecrocoagulation, both flaps were rotated towards the surgical defect and sutured to each other, forming a transversal scar aligned with the oral commissures (Figures 3 and 4 ).

The surgical procedure was performed in a single stage without intercurrences. Postoperative complications were not reported and the final esthetic result was very satisfactory, with total preservation of lip function.

\section{DISCUSSION}

The double rhomboidal flap is a viable option for reconstructing large surgical defects of the oral commissures. The transposition of two symmetric rhomboidal flaps obtained in opposing donor skin areas allows the annulment of local tension forces, minimizing the risk of local deformation, particularly the distortion of the oral commissure. ${ }^{4}$ This is, in fact, the main advantage of this reconstructive technique, avoiding cosmetically inacceptable lip asymmetries and oral sphincter dysfunction. The closure of the secondary surgical defects contributes to compensation of the tension forces, stabilizing the perioral area and originating scars that are partially coincident with anatomic folds.

It is a technically simple procedure, easily per-

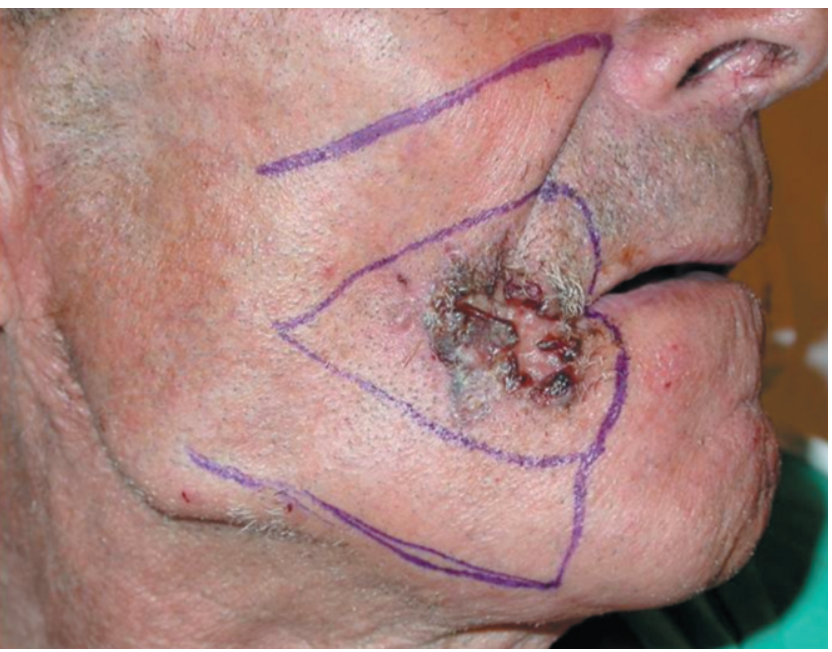

FIGURE 2: Definition of the surgical margins for radical tumour excision and donor skin areas 


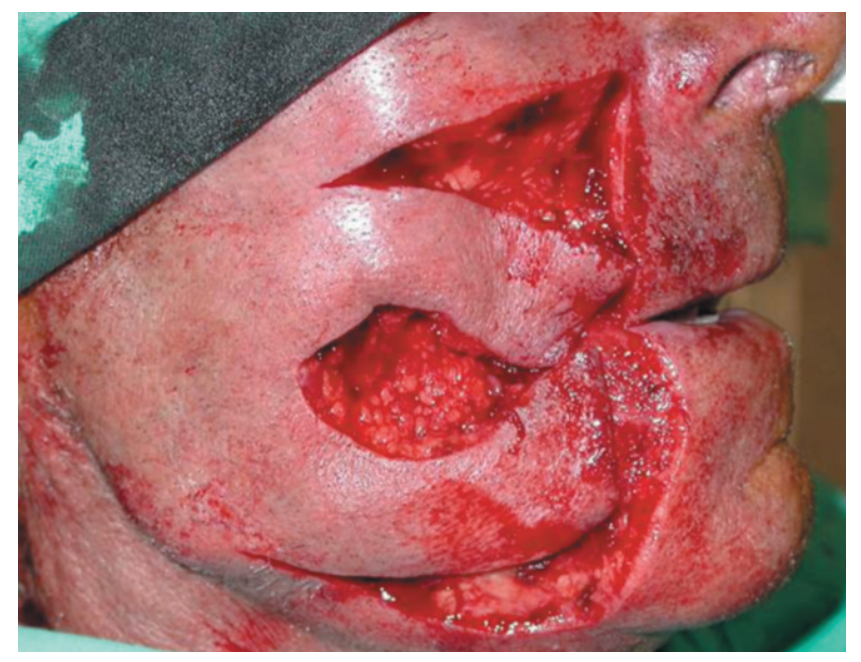

Figure 3: Transposition of the rhomboidal flaps towards the surgical defect after radical tumour excision

formed under local anesthesia in a single stage, and highly versatile, as it has been described for reconstruction of surgical defects in diverse skin areas, not exclusively in the face. ${ }^{4.7}$ In the described case, despite originating three parallel scars disposed across the

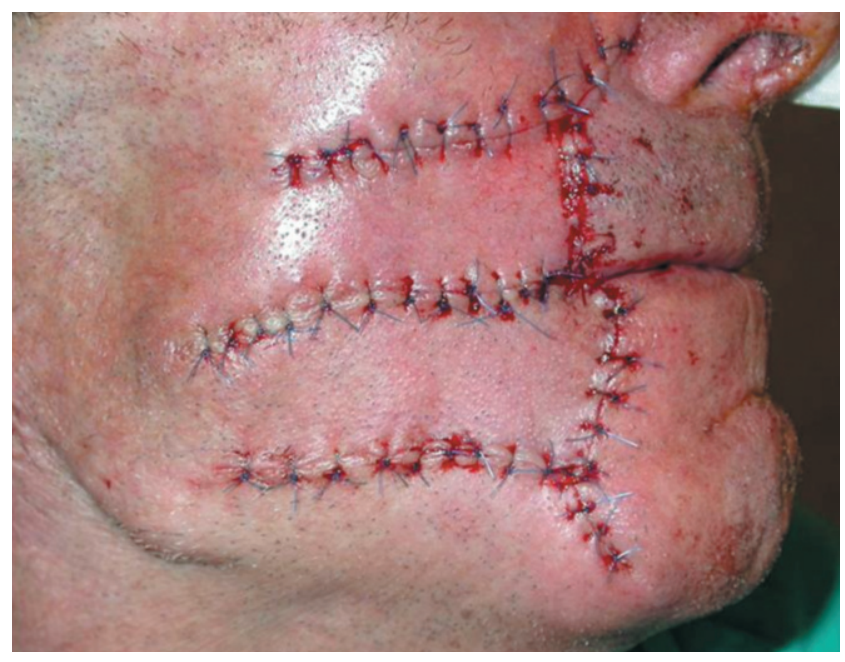

FIGURE 4: Double rhomboidal flap - final result

cheek and mandibular areas, we consider that the reasonable cosmetic result is highly compensated by the structural and functional benefit concerning the lip and perioral architecture.

\section{REFERENCES}

1. Almeida AC, Yamashita T, Conte B, Mattos AC, Veríssimo RP, Ferreira MC Freqüência do carcinoma basocelular na população menor de 50 anos: estudo do serviço e revisão de literatura. An Bras Dermatol. 2009;84:692-4

2. Custódio G, Locks LH, Coan MF, Gonçalves C0, Trevisol DJ, Trevisol FS Epidemiologia dos carcinomas basocelulares em Tubarão, Santa Catarina (SC), Brasil, entre1999 E 2008. An Bras Dermatol. 2010;85:819-26.

3. Nunes DH, Back L, Silva RV, Medeiros VS. Incidência do carcinoma de células escamosas da pele na cidade de Tubarão (SC) - Brasil nos anos de 2000, 2003 e 2006 An Bras Dermatol. 2009;84:482-8.

4. Wu HL, Le SJ, Zheng SS. Double opposing-rhomboid flaps for closure of a circular facial defect in a special position. Aesthetic Plast Surg. 2009;33:523-6.

5. Akyürek M, Safak T. Direct closure of radial forearm free-flap donor sites by double-opposing rhomboid transposition flaps: case report. J Reconstr Microsurg. 2002;18:33-6.

6. Bullock JD, Hamdi B. Double rhomboid flap in ophthalmic plastic surgery. Ophthalmic Surg. 1980;11:431-4.

7. El-Tawil S, Carapeti E. Use of a double rhomboid transposition flap in the treatment of extensive complex pilonidal sinus disease. Colorectal Dis. 2009;11:313-7.

\author{
MAILING ADDRESS / ENDEREÇO PARA CORRESPONDÊNCIA: \\ Pedro Andrade \\ Serviço de Dermatologia e Venereologia \\ Hospitais da Universidade de Coimbra, EPE \\ Praceta Mota Pinto \\ 3000-075 Coimbra, Portugal \\ E-mail:pedro.andrade@portugalmail.com
}

How to cite this article: Andrade P, Brinca A, Vieira R, Figueiredo A. Double rhomboidal flap for reconstruction of large surgical defect of the labial commissure. An Bras Dermatol. 2012;87(3):456-8. 